\title{
Ocular manifestations of COVID-19: a literature review
}

\author{
(iD)Bruna Rafaella Santos Torres ${ }^{1}$ \\ (iD) Carlos Eduardo Ximenes da Cunha ${ }^{1}$ \\ (iD) Laís Rytholz Castro ${ }^{1}$ \\ (D) Lara Medeiros Pirauá de Brito ${ }^{1}$ \\ (iD Caio Victor Oliveira Ferreira ${ }^{1}$ \\ DMarina Viegas Moura Rezende Ribeiro
}

1. Acadêmico(a) de Medicina da Universidade Tiradentes, Maceió, AL, Brasil. 2. Especialista em Oftalmologia, Doutora em Ciências da Saúde, Professora da Universidade Tiradentes, Maceió, AL, Brasil.

http://dx.doi.org/10.1590/1806-9282.66.9.1296

\section{SUMMARY}

Coronavirus disease 2019 (COVID-19) caused by the highly pathogenic SARS-Cov-2 virus, was declared as a pandemic by the World Health Organization (WHO) in March 2020. Its main clinical manifestations are related to airway involvement; however, there is extrapulmonary impairment in some cases. Given this context, this literature review aims to identify the ophthalmological conditions caused by infection with the novel coronavirus. Although ocular findings do not include the standard clinical presentation of the disease, there are reports of some ophthalmological changes in COVID-19 patients, and conjunctivitis is the most common among these.

KEYWORDS: Coronavirus Infections. Pandemics. Signs and Symptoms. Ophthalmology. Conjunctivitis.

\section{INTRODUCTION}

Viruses circulate in humans, birds, and other animals causing epidemics and pandemic outbreaks throughout history, as was the case with H1N1 (Spanish flu) and H3N2 (Hong Kong fever), in 1968, which resulted in over 1 million deaths'.

On 11 March 2020, the World Health Organization (WHO) declared a pandemic caused by novel coronavirus NCOV-19, which causes Sars-COV-2, Severe Acute Respiratory Syndrome with systemic repercussions, such as organ failure and septic shock ${ }^{2.3}$. Since the pandemic was announced, the number of new COVID19 cases (Coronavirus disease) has increased dramatically outside the Chinese territory, with 143 countries reporting infections by NCOV-19 to the $\mathrm{WHO}^{4}$.
The first cases of the disease were reported in the city of Wuhan, in the Hubei province of China, where the patients had symptoms such as dry cough, dyspnea, fever and bilateral pulmonary infiltrates in imaging examinations. In addition to these signs and symptoms, after a more detailed analysis through nasopharyngeal swabs, the causal agent was identified by the Chinese Center for Disease Control and Prevention as Sars-CoV-2 ${ }^{3}$.

Sars-CoV-2 is a single-stranded RNA virus with immunological characteristics similar to Sars-CoV- $1^{5}$. This pathogen is part of the beta-coronavirus family and has a great diversity of non-structural proteins and spike proteins that interact heavily with the 
receptors of angiotensin-converting enzyme 2 (ACE2) in the human body ${ }^{5}$. ACE2 is more concentrated in the lung, heart, renal and intestinal tissue ${ }^{6}$. In the lung, the receiver is expressed in epithelial cells, which suggests a relationship between ACE2 and the characteristic alveolar damage of COVID-19 patients ${ }^{7.8}$.

The immune response to the virus is mediated by T-lymphocytes through antigen-presenting cells and alveolar macrophages, which have ACE2 receptors. Thus, there is an inflammatory phenomenon perpetuated by CD-4 and cellular destruction mediated by cytotoxic $\mathrm{CD} 8{ }^{7}$.

The ocular tissue is also a site of ACE2 expression, which is present in the cornea and in the conjunctiva epithelial cells ${ }^{9.10}$. This receptor is associated with the maintenance of intraocular pressure and presents an important role in the physiopathology of COVID-19 ${ }^{11}$.

Since the ocular surface can serve as a gateway to various pathogens, it is believed that this includes the coronavirus ${ }^{12}$. Considering this is an ideal environment for the virus adhesion due to its tropism related to the surface receptor, some authors postulate that the contact of the ocular surface with objects and hands contaminated by the virus can serve as the initial site of infection, which then spreads ${ }^{12.13}$.

The existence of ACE2 in the corneal limbus allows the beta-coronavirus to cross the ocular surface and spread to other parts of the body, either through the hematogenic route or the nervous system, through the trigeminal nerve ${ }^{14}$.

The presence of eye signs and symptoms and the possibility of NCOV infection-19 through contaminant droplets in the conjunctiva have aroused the interest of medical institutions. The adoption of preventive measures for individual eye protection and the early recognition of ocular symptoms in patients with suspected COVID-19, thus, have been identified as essential ${ }^{13.15}$.

Although this is a very current scenario, there are some reports of ocular manifestations in patients with a diagnosis of COVID-19 ${ }^{15}$. The most frequent finding of ocular involvement is viral conjunctivitis, presenting redness, lacrimation, and foreign body sensation from the $13^{\text {th }}$ day of the disease or as the first sign of infection ${ }^{16-18}$.

Although conjunctivitis is not a classical or standard presentation of the novel coronavirus, physicians and ophthalmologists should be aware of patients complaining of this symptoms ${ }^{8}$. This study aims to identify and analyze the main ocular complaints resulting from viral infection by Sars-Cov-2.

\section{METHODS}

The current work is a literature review of the main ocular manifestations found in COVID-19 patients. A search was carried out in the PubMed, SciELO, and Lilacs databases using keywords such as Ocular findings and COVID-19, as well as ocular manifestation and coronavirus. As a result, we found some initial studies from 2019-2020 and selected those that fit into the proposed theme; eight works remained for analysis.

\section{RESULTS AND DISCUSSION}

The acute respiratory disease caused by the novel coronavirus spread beyond the Chinese territory and drew attention worldwide. NCOV-19 uses ACE2 to attach, in particular, to the respiratory epithelium and achieve systemic circulation in the host ${ }^{19}$.

Recognizing the ocular manifestations in patients infected by the coronavirus is necessary in order to understand the role of ophthalmology at the frontline. Since viral RNA has already been found in the conjunctiva $^{9.10}$, ophthalmologists have a relevant role in combating this pandemic, i.e., predicting the risk of clinical complications in patients and clarifying the importance of the ocular surface in the transmission of the disease, since there are few studies published on this subject ${ }^{20}$.

A study conducted in February 2020 in the Yichang Central People's Hospital made a retrospective analysis of 38 patients hospitalized due to COVID-19. Of these, only two had positive nasopharyngeal and conjunctival swabs, and 12 (31\%) presented ocular manifestations such as conjunctival hyperemia, increased secretion, and epiphora ${ }^{15}$.

In this study, it was observed that $50 \%$ of the cases of the novel coronavirus with ocular symptoms occurred in patients classified as severe and critical, based on the Guideline for the Prevention and Control of COVID-19 ${ }^{15.21}$. Added to this, in laboratory findings, there was a greater count of white blood cells, neutrophils, lactic dehydrogenase, and C-reactive protein when compared to patients without visual complaints ${ }^{15}$.

Parallel to this study, 535 patients were recruited by the Optical Valley and Tongji Hospital of the University of Science and Technology of Huazhong in WuHan, China. Of the total number of patients, about $20 \%$ had dry eye, $12 \%$ blurred vision, $11 \%$ foreign body sensation,10\% epiphora, and 9\% increased ocular secretion ${ }^{11}$. 
Among the complaints reported, dry eye, blurred vision, and foreign body sensation were symptoms compatible with those of the patients analyzed in the study by the Yichang Central People's Hospital ${ }^{11.15}$. In addition, it was concluded that conjunctival congestion is not common (only $5 \%$ of patients) and that the ocular manifestations generally occur early in COVID-19 ${ }^{11}$.

Since the symptoms reported by coronavirus patients are common complaints in ophthalmology, ophthalmologists can be the first professional sought by patients with COVID-1922. Thus, it is essential, in these cases, that patients perform an active search for other signs and symptoms, particularly those related to the respiratory system, bearing in mind the current epidemiological context ${ }^{23}$.

In Thailand, a study with 48 patients positive for COVID-19 used direct ophthalmoscopy and corneal scraping in patients with suspected cases of conjunctivitis. Of the individuals examined, no eye problems were reported. However, the author emphasized that ocular manifestations are often ignored by the Thailandese ${ }^{23}$. In addition, ophthalmological symptoms of the disease can go easily unnoticed since they initially present as nonspecific manifestations ${ }^{24}$.

At the hospital of the University of Zhejiang, an interview was carried out with 56 hospitalized patients diagnosed with COVID-19. A questionnaire was applied with these patients in order to evaluate the quality of their ocular surface, based on the Ocular Surface Disease Index, before and after the disease ${ }^{24}$.
The main ophthalmic complaints of patients were increased secretion, foreign body sensation, dry eye, and red-eye, and these findings are compatible with those of other studies ${ }^{11,15,24}$. Regarding the time of onset of ocular signs and symptoms, in most cases they preceded the respiratory symptoms in a few days, emphasizing the importance of giving proper value to these complaints in the current situation ${ }^{24}$.

In addition, it was noted that the dry eye score pf patients before the novel coronavirus was compatible with the average indices of the Chinese population; however, there was a significant increase in it after the infection, suggesting that the dry eye can be an extrapulmonary manifestation of the disease ${ }^{24}$.

In Italy, a study involving five patients with nasopharyngeal swab positive for COVID-19, in April 2020, reported that all individuals analyzed presented acute conjunctivitis as the only manifestation of the disease $^{25}$. The complaints of the patients included hyperemia, increased secretion, epiphora, and photophobia, in the absence of other systemic symptoms, and this was less common symptomatology in comparison to the findings of most studies involving ocular symptoms secondary to infections by the new coronavirus ${ }^{25}$.

A case report of a 27-year-old patient demonstrates viral conjunctivitis as an initial symptom of severe COVID- $19^{18}$. The study depicts an Argentinian individual who developed a foreign body sensation and evidence of swollen eyelid, conjunctival hyperemia, and red-eye, evolving after 12 hours into a fever with sudden dyspnea ${ }^{18}$.

FIGURE 1. PROBABLE PHYSIOPATHOLOGICAL MECHANISM OF THE SARS-COV-2 INFECTION THROUGH THE OCULAR SURFACE.

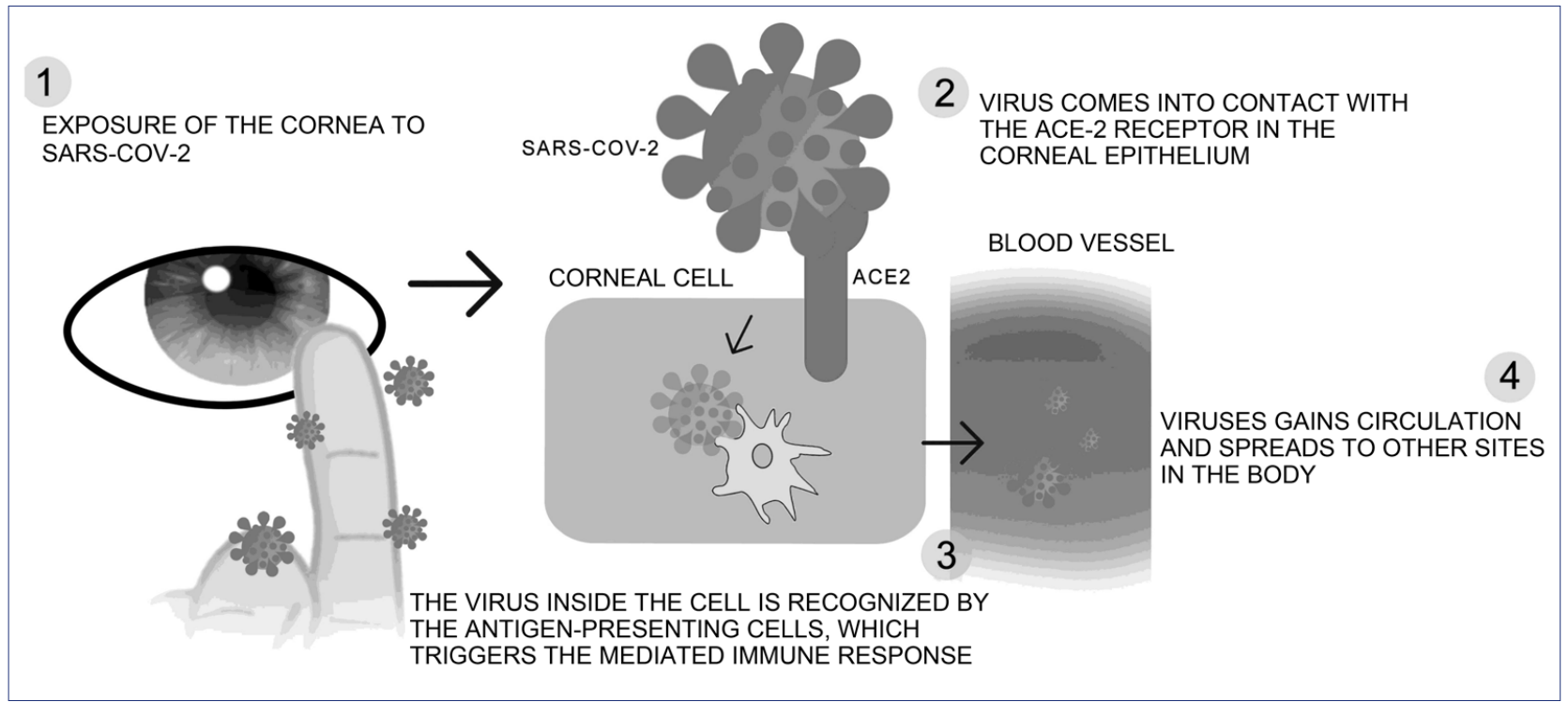

Source: Cunha CEX, 2020. This figure was designed using Freepik.com resources (https://br.freepik.com/). The physiopathology illustrated was described by Napoli et al. ${ }^{2}$. 
FIGURE 2. ACE2 RECEPTOR DISTRIBUTION IN DIFFERENT ORGANS OF THE HUMAN BODY.

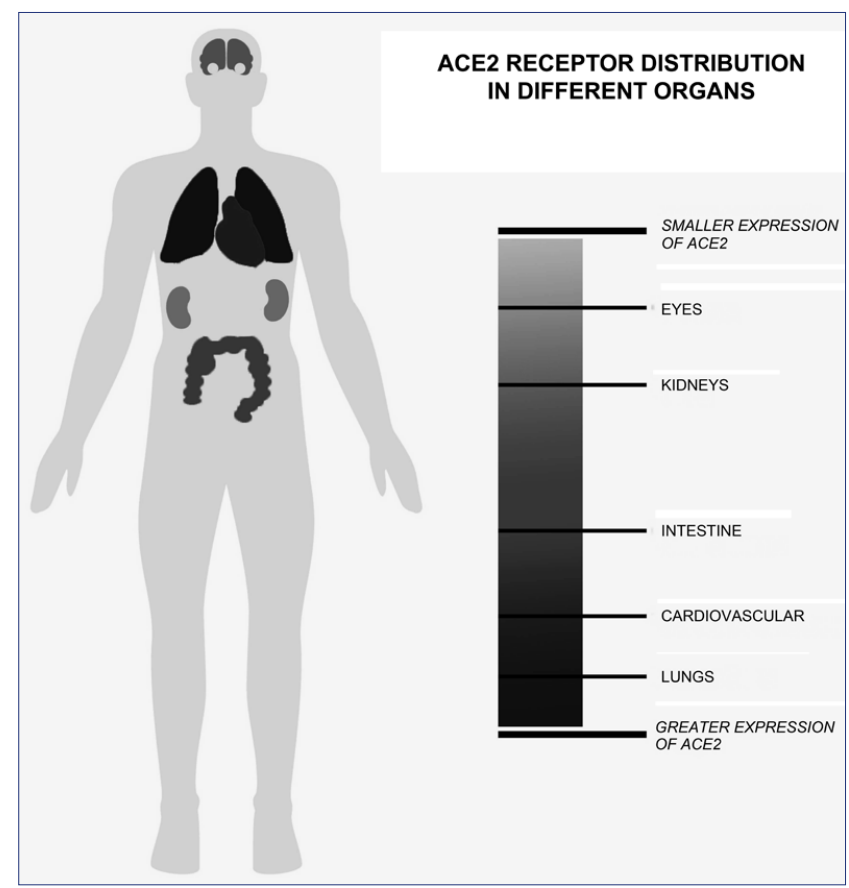

Source: Cunha CEX, 2020. This figure was designed using Freepik.com resources (https://br.freepik.com/). Distribution of the ACE2 receptor in different tissues of the body as presented by Amesty et al. ${ }^{\text {? }}$

\section{CONCLUSION}

In the abovementioned reports it is possible to see that, despite the very recent context, studies demonstrate that ocular manifestations may present as the initial or exclusive complaints from the novel
TABLE 1. MAIN OCULAR MANIFESTATIONS OF COVID-19.

Main ocular manifestations of COVID-19
Conjunctival hyperemia
Foreign body sensation
Dry eye
Photophobia
Epiphora
Blurred vision
Eyelid swelling
Increased secretion

Main ocular manifestations described in articles reviewed for this study.

coronavirus, even though this is not the most common and standard presentation. Among these ophthalmologic findings is viral conjunctivitis, which may evolve with hyperemia, foreign body sensation, swollen eyelid, epiphora, increased secretion, in addition to dry eye, and blurred vision.

Therefore, it is necessary to broaden our understanding of this new pathology and identify its extrapulmonary manifestations to fully evaluate patients so that we can understand the role of ophthalmology at the frontline. In addition, since viral RNA has been found in the conjunctiva in some studies, the role of health care professionals is shown to be important in guiding the population regarding the care in handling the ocular surface ${ }^{9.10}$.

\section{Author's Contribution}

All authors contributed equally to this work.

\section{RESUMO}

A doença do coronavírus 2019 (COVID-19) causada pelo vírus, altamente patogênico, Sars-Cov-2, foi declarada como uma pandemia pela Organização Mundial da Saúde (OMS) em março de 2020. As principais manifestações clínicas se relacionam com o acometimento da via aérea; no entanto, há em alguns casos comprometimento extrapulmonar. Perante esse contexto, esta revisão de literatura objetiva identificar as condições oftalmológicas resultantes da infecção pelo novo coronavírus. Apesar de os achados oculares não contemplarem o quadro clínico padrão da doença, há relatos de algumas alterações oftalmológicas em pacientes com COVID-19 positivo, sendo a conjuntivite a mais comum entre estas.

PALAVRAS-CHAVE: Infecções por coronavírus. Pandemias. Sinais e sintomas. Oftalmologia. Conjuntivite.

\section{REFERENCES}

1. Boopathi S, Poma AB, Kolandaivel P. Novel 2019 coronavirus structure, mechanism of action, antiviral drug promises and rule out against its treatment, J Biomol Struct Dyn. 2020;1-10.

2. Lana RM, Coelho FC, Gomes MFDC, Cruz OG, Bastos LS, Villela DAM, et al. The novel coronavirus (SARS-CoV-2) emergency and the role of timely and effective national health surveillance. Cad Saude Publica. 2020;36(3):e00019620.

3. Sohrabi C, Alsafi Z, O'Neill N, Khan M, Kerwan A, Al-Jabir A, et al. World Health Organization declares global emergency: a review of the 2019 novel coronavirus (COVID-19). Int J Surg. 2020;76:71-6.
4. Ul Qamar MT, Alqahtani SM, Alamri MA Chen LL Structural basis of SARSCoV-2 3CL and anti-COVID-19 drug discovery from medicinal plants. J Pharm Anal. 2020. doi: 10.1016/j.jpha.2020.03.009.

5. Zou X, Chen K, Zou J, Han P, Hao J, Han Z. Single-cell RNA-seq data analysis on the receptor ACE2 expression reveals the potential risk of different human organs vulnerable to 2019-nCoV infection. Front Med. 2020;14(2):185-92.

6. Yuki K, Fujiogi M, Koutsogiannaki S. COVID-19 pathophysiology: a review. Clin Immunol. 2020;215:108427. 
7. Xu Z, Shi L, Wang Y, Zhang J, Huang L, Zhang C, et al. Pathological findings of COVID-19 associated with acute respiratory distress syndrome. Lancet Respir Med. 2020;8(4):420-2.

8. Wang L, Wang Y, Ye D, Liu Q. Review of the 2019 novel coronavirus (SARS-CoV-2) based on current evidence. Int | Antimicrob Agents. 2020;55(6):105948.

9. Amesty MA, Alió Del Barrio JL, Alió JL. COVID-19 disease and ophthalmology: an update. Ophthalmol Ther. 2020;1-12.

10. Holappa M, Vapaatalo $H$, Vaajanen $A$. Many faces of renin-angiotensin system: focus on eye. Open Ophthalmol J. 2017;11:122-42.

11. Willcox MD, Walsh $K$, Nichols J), Morgan PB, Jones LW. The ocular surface, coronaviruses and COVID-19. Clin Exp Optom. 2020;103(4):418-24.

12. Napoli PE, Nioi M, d'Aloja E, Fossarello M. The ocular surface and the coronavirus disease 2019: does a dual 'ocular route' exist? J Clin Med. 2020;9(5):1269.

13. Sungnak W, Huang N, Bécavin C, Berg M, Queen R, Litvinukova M, et al. SARS-CoV-2 entry factors are highly expressed in nasal epithelial cells together with innate immune genes. Nat Med. 2020;26(5):681-7.

14. Wu P, Duan F, Luo C, Liu O, Qu X, Liang L, et al. Characteristics of ocular findings of patients with coronavirus disease 2019 (COVID-19) in Hubei Province, China. JAMA Ophthalmol. 2020;138(5):575-8.

15. Seah I, Agrawal R. Can the coronavirus disease 2019 (COVID-19) affect the eyes? A review of coronaviruses and ocular implications in humans and animals. Ocul Immunol Inflamm. 2020;28(3):391-5.

16. Chen L, Liu M, Zhang Z, Qiao K, Huang T, Chen M, et al. Ocular manifestations of a hospitalised patient with confirmed 2019 novel coronavirus disease. Br J Ophthalmol. 2020;104(6):748-51.
17. Daruich A, Martin D, Bremond-Gignac D. Ocular manifestation as first sign of Coronavirus Disease 2019 (COVID-19): interest of telemedicine during the pandemic context. J Fr Ophtalmol. 2020;43(5):389-91.

18. Guo YR, Cao OD, Hong ZS, Tan YY, Chen SD, Jin HJ, et al. The origin, transmission and clinical therapies on coronavirus disease 2019 (COVID-19) outbreak: an update on the status. Mil Med Res. 2020;7(1):11.

19. Jain P, Pattnaik A, Bhatnagar VC. Ophthalmology in the time of corona: Measures taken in a tertiary eye care hospital in Rajasthan against COVID-19 spread. Indian J Ophthalmol. 2020;68(5):949-50.

20. National Health Commission of the People's Republic of China. The guideline on diagnosis and treatment of the novel coronavirus pneumonia (NCP): revised version of the $5^{\text {th }}$ edition. [cited 2020 Feb 8]. Available from: http://www.nhc.gov.cn/xcs/zhengcwj/202002/d4b895337e19445f8d728fcafle3e13a.shtml

21. HuK, Patel I, Patel BC. Ophthalmic manifestations of coronavirus (COVID19). In: StatPearls. Treasure Island: StatPearls Publishing; 2020.

22. Li JO, Lam DSC, Chen Y, Ting DSW. Novel coronavirus disease 2019 (COVID-19): the importance of recognising possible early ocular manifestation and using protective eyewear. Br J Ophthalmol. 2020;104(3):297-8.

23. Mungmungpuntipantip R, Wiwanitkit V. Ocular manifestation, eye protection, and COVID-19. Graefes Arch Clin Exp Ophthalmol. 2020;258(6):1339.

24. Hong N, Yu W, Xia J, Shen Y, Yap M, Han W. Evaluation of ocular symptoms and tropism of SARS-CoV-2 in patients confirmed with COVID-19. Acta Ophthalmol.2020;10.1111/aos.14445.

25. Scalinci SZ, Trovato BE. Conjunctivitis can be the only presenting sign and symptom of COVID-19. IDCases. 2020;20:e00774. 